\title{
Silence and its mechanisms as the discursive production of the 'normal' in the early childhood classroom
}

\author{
Karen Watson', Zsuzsa Millei ${ }^{2}$, Eva Bendix Petersen ${ }^{3}$
}

\begin{abstract}
In this paper, we aim to better understand and trouble the discursive (re)production of what is taken as the 'normal' in 'inclusive' early childhood classrooms. We do so by exploring the practices of the 'including' group, the so-called 'normal, in relation to or in the presence of those who are variously labelled as 'non-normal'. We highlight those mechanisms that are associated with silence and taboo, and through which the including group produces and maintains itself. We present data produced during a six-month ethnographic study in three early childhood classrooms in Australia. Using the notion of category boundary work in the analysis, we illuminate the practices of silence: 'ignoring', 'moving away', 'turning away' and 'keeping silent' through which children undertake the category work of the 'normal'. The effect of this category work, we argue, is that disability or the diagnosed subject becomes 'the elephant in the room', strongly present but avowedly ignored. We draw out some considerations for practice in the concluding part of the paper.
\end{abstract}

\author{
Article History \\ Received: 27 February 2020 \\ Accepted: 14 May 2020 \\ Keywords \\ Category boundary work \\ Inclusion; Taboo; \\ Poststructural; Normal; \\ Early childhood; \\ Ethnography
}

\begin{abstract}
... from a discourse theoretical point of view, it is not possible to explain why communities are more or less inclusive. We can only investigate how the inclusion and exclusion processes take place and get a better and deeper understanding of these processes (Hedegaard Hansen, 2012, p. 97).
\end{abstract}

\section{Introduction}

In the above quote Hedegaard Hansen (2012) calls for the exploration of social practices in everyday settings through which inclusion and exclusion happen. More specifically, Hedegaard Hansen (2012) and others argue for exploring the idea and mechanics of inclusion around dilemmas such as, who needs to participate in the including, what are the limits of inclusion, what structural issues obstruct inclusion, and 'into what' does inclusion needs to happen (Davis \& Watson, 2001; Graham, 2006). Inclusive early childhood education in Australia as in other parts of the world is an obligation (Nutbrown \& Clough, 2009; United Nations Educational, Scientific and Cultural Organization [UNESCO], 1994) but exclusionary structures and practices form considerable obstacles to the realization of this commitment (Cologon, 2014). The idea of 'inclusion' implies that there is a 'need' to include and that there is somewhere to be included into. Graham (2006) defines 'inclusion' as a 'bringing in' which implies a dualism, where there are those who are 'automatically' and 'naturally' included - the 'normal', and those who are 'automatically' not included but are in 'need' of including. Therefore, the challenge for inclusive practice is not to think about how to do inclusion better (Slee, 2013). Instead, inclusive practice is about detecting, understanding and dismantling exclusion as it presents itself in education. It entails exploring the mechanics of inclusion and exclusion.

In this article, we set out to identify and problematize some of the mechanisms of 'inclusion' practiced by the including group, or the 'normal'. This exploration remains important since research often

\footnotetext{
${ }^{1}$ University of Newcastle, Faculty of Education and Arts, Newcastle, Australia, e-mail: karen.watson@newcastle.edu.au ORCID: https://orcid.org/0000-0002-5456-1888

2 Tampere University, Faculty of Education and Culture, Tampere, Finland, e-mail: Zsuzsa.Millei@tuni.fi ORCID: https://orcid.org/0000-0003-4681-6024

${ }^{3}$ Roskilde University, Department of People and Technology, Roskilde, Denmark email: evabp@ruc.dk ORCID: https://orcid.org/0000-0003-4583-6007
} 
highlights how, from the perspectives of children with special needs, the experience of inclusion often comes with "exclusion, isolation, loneliness, and bullying, and difficulties finding friends" (MacArthur, 2013, p. 793). The concept of 'inclusion' is not well defined or understood in education. The illusion of 'inclusion' as a finished product (Slee \& Allan, 2001) is potentially problematic Graham and Slee (2008) argue that inclusion infers a 'benign commonality' where unchallenged assumptions view inclusion as a taken-for-granted phenomenon, with a shared common meaning and understanding. This is however potentially dangerous as it conceals differences and creates a hazardous familiarity that avoids confronting or talking about difference (Allan, 2010).

The problem of inclusion is often located 'within the child' as a deficit (Davis \& Watson 2001; Harwood, 2006). At the same time, regulatory practices in early childhood education seek to "normalize" children deemed to have deficits (Dalkilic \& Vadeboncoeur, 2016). This deficit driven medical model perspective (Purdue, 2009; Slee, 2010) together with the ubiquitous developmental and psychological thinking that orientates diagnosis of any deviance from the norms, are firmly embedded in early childhood classrooms (Burman, 2008; Cannella, 1997). The societal and educational focus on the child 'in need of including', is detrimental to all children as it assigns privilege to the 'normal' while marginalizing those who do not fit the normalized vision, producing them as deficient, wrong or abnormal (Walkerdine, 1988).

In this study, we turn away from the child to be included and focus on the including group, those without a diagnosis, what we term here as the 'normal', the peers who participate in the including. In current special and inclusive education relations with peers are less explored (Ferreira, 2018). Focusing on peers also troubles the individualizing gaze that further marks the child as 'the problem' and fixes the child's position at the margin. Drawing on data produced as part of a larger study (Watson, 2015), we examine some of the complex ways in which young children act in inclusive settings, re/producing and guarding their position of being included, or being 'normal', and how they further mark and exclude the 'others' in early childhood settings. This is an important concern as "the main motives of parents for sending their child with a special need to a regular school ... is to grow up as far as possible in a normal environment" (Koster, Nakken, Pijl, \& van Houten, 2009, p. 118, our emphasis) i.e. in an environment together with the so called normal peers. In this paper, we explore some of the mechanisms through which the 'normal', the norms that position the including children as such, are mobilised and exercised by 'normal' children (children without a diagnosis).

\section{Methodology}

Foucault (1977, p. 184) describes the norm as "the new law of modern society" as it gives muscle to a homogenous social body. The norm imposes uniformity and at the same time individualises and marginalises those who differ. Psychological sciences have produced the technical means of individualization (Petersen and Millei, 2016). These are applied in institutional settings, such as the early childhood classroom where comparisons to norms and judgements are made about children by their teachers and by children. Those who 'measure up' are categorised as 'normal' subjects and those who do not fit the parameters are classified as the different or 'not normal' subjects.

This exploration of the normal follows poststructural thinking (Davies, 1993, 1998; Foucault, 1977; Law \& Davies, 2000; Petersen, 2004) by paying attention to the constitutive force of discourse and particular discursive practices (Davis \& Harré, 1999). We explore 'What is going on in situations?' and focus on the particularities and complexities of lives in context, always paying attention to how the researcher herself mediates and creates the data that is being produced (Stronach \& MacLure, 1997). The focus is on discourses understood as meaning-systems and meaning-making, recognising how everyday utterances and actions are linked into larger 'regimes of truth'. Thus, we are interested in examining what discourses do, what their effects are in the constitution of the 'normal' and for so called 'inclusionary practices' (Foucault, 1972).

Thinking with childhood studies (James, Jenks, \& Prout, 1998) and acknowledging that our positioning is a discursive construction itself, we view young children from an early age as capable, 
Silence and its mechanisms as the discursive production...

competent, and active negotiators in their social world and aware of diversity and difference (Cannella, 1997; Davies, 1989). In the process of becoming a culturally intelligible person, children learn to navigate binaries offered to them as a way of making sense of themselves and others: male/female, white/black, ablebodied/disabled, etc. Davies (1989) argues that children also learn that the categories in the binary are not equal, but that one is relatively subjugated. This awareness shape the ways children behave toward others and go about their everyday activities (Beazley \& Williams, 2014; Davis \& Watson, 2001; Koster et al., 2009; Robinson \& Jones-Diaz, 2006). Young children identify normalising discourses around their own identities and adjust their actions accordingly. They observe norms and the behaviour of others around them, and decide whether or not those are applicable or the same or different to their behaviours (Robinson \& JonesDiaz, 2006). The early childhood classroom is arguably the first institution, other than the family and the media, that introduces children to the world of human as well as nonhuman differences (Millei and Cliff, 2014). By using norms, labels and categories made available to them via the discourses in a particular context, children readily include and exclude their peers based on their differences (Connolly, Smith, \& Kelly, 2002; Davis \& Watson, 2001). Thinking with these ideas about children, difference and the 'normal', the data was created.

The data was created over a six-month period using ethnographic methods in three Australian early childhood settings. Ethnographic methods are regarded as a key approach in exploring the social worlds of young children (Alderson, 2008; Christensen, 2004; James et al. 1998; Traweek, 1988). The research participants included both the children and the educators in the classrooms. Informed and ongoing consent was obtained from parents, carers and educators as well as from the children themselves. The study received approval from the University of Newcastle's ethics committee. Multiple classrooms were invited to participate with three assenting. The classrooms, all located within early childhood centres, were situated in two regional urban centres of New South Wales, Australia. While each preschool classroom was unique in its own way, they all provided for the most part, a 'standard' child-centred program. Approximately, 75 children aged between two and six years, and twelve educators participated in the project. All the participants' names have been replaced with pseudonyms. Each classroom had several children with a diagnosis enrolled. There is intentionally no commentary on the children's diagnostic labels. The discursively produced labels and associated homogenising characteristics that define and prescribe the diagnosed child, and their behaviours, are challenged in this study. The child is marked by the diagnosis bestowed upon them. The 'details' of the diagnosis do not alter the child's marked position among the children. Making no mention of the diagnosis is one way of disrupting acknowledgement of it, of 'refusing to be in the know'.

In creating the data, close attention was paid to the undiagnosed children's encounters with and around each other and the diagnosed child/children. Sometimes photos of the children were used to start conversations about their encounters with each other and their daily activities. The conversations were often audio-recorded, always with the children's and their parent's consent. The diagnosed child was initially the focus of the photographs as they went about their day in the play context, in an attempt to elicit conversations. The child with a diagnosis became inadvertently conceptualised and viewed as a catalyst in this study, allowing for the examination of the normal and its discursive constitution. However, it became apparent that the children liked to see themselves in the photos and talked about what they were doing, rather than talking about the diagnosed child. Moreover, they seemed to find discussions about the diagnosed child uncomfortable, usually changing the topic of the conversation or being silent. Looking reflexively, this strategy may have in some ways inadvertently contributed to the diagnosed child's marked position, it did however, allow for the workings of the normal to be clearly observed. The uncomfortable feelings of peers disappeared by changing the conversation and they could also leave the situation freely.

Adopting a poststructural perspective, the researcher observed and participated with children and their educators in daily practices, in which she focused on the operation of discourses, knowledges and power relations that produced particular subject positions, privileging the 'normal', while subordinating others. As heuristics to analyse the data and inspired by Foucauldian discourse analysis, we used positioning theory (Davies, 1989) and the analytical concept of category boundary work (Petersen, 2007). 
Positioning theory proposes that discourses make certain subject positions available to people and these subject positions are negotiated and constituted relationally (Harré \& van Langenhove, 1999, p. 16). Children learn how to position themselves within discourses and variously take up membership in associated categories in social practice. Once having taken up a position as one's own in a situation, the person sees the world from that vantage point with those storylines, images, metaphors and concepts that this position shores up (Davis \& Harré, 1999). Categories are linked to actions that are taken for granted as characteristic activities of a member of the category (MacLure, Jones, Holmes, \& MacRae, 2012). Importantly, positioning is not static and fixed but one that is constituted and reconstituted through the shifting situations and many discursive practices in which a person might participate.

The following is a selection of scenarios that illustrate how the unmarked 'normal' children took up particular category membership positions made available via multiple circulating discourses when they encountered a child with a diagnosis. Having taken up their membership, the children work on knowing how to belong and they also aspire to be correctly located as a member (Davies, 1993). They engage in category maintenance work to uphold this membership. In this way, the 'normal' is produced, reproduced and maintained in the social practices of the children and the classroom by the ways each acts, talks, and shifts his/her/their practices; this is made discernible most clearly and dramatically in the effects that these practices produce (Butler, 2004, p. 41).

Our choice of term, 'child with a diagnosis' is intentional to describe how the child is marked by psychological and medical discourses and consequently how the child's identity is produced in the classroom (Davis \& Watson, 2001). Using this term emphasises that the child 'was given' this position by a medical, psychological or educational professional, and therefore was 'marked' by this diagnosis as different to or compared to others who are considered 'normal'. The 'child with a diagnosis' became the catalyst for examining the active and sustained production and maintenance of the 'normal' more visible. While we aimed to maintain our focus on children without a diagnosis, the 'child with a diagnosis' is still present in our explorations.

\section{Practices That Re/Produce the 'Normal' and Their Effects}

There are multiple discourses in the classroom that prescribe what it is to be and act as 'normal', such as being 'big' and 'little', 'friend' or 'not friend', 'helping' and 'being helped', or 'I have learned this' and 'they are just learning'. While prevalent in the children's narratives and also in their practices, these discourses were also obvious in actions that were not accompanied by words. In this paper, we turn our attention to the things that were not seen, not said and not heard. The focus is to explore the 'silences' as they are a critical part of the whole, "the relevant speech act 'spoken' beneath the surface" (Mazzei, 2007, p. xii). As Foucault (2008, p. 27) explains:

'Silence' is considered a discursive practice. Silence itself - the things one declines to say, or is forbidden to name, the discretion that is required between different speakers - is less the absolute limit of discourse, the other side from which it is separated by a strict boundary, than an element that functions alongside the things said, with them and in relation to them within over-all strategies.

Keeping 'silent', being 'silent' or not speaking, or perhaps moving out from the situation or speaking about something in different terms in order to avoid speaking, are examples of what could be cogitated as discursive moves (Mazzei, 2007). Silences contribute to the meaning between words that helps to think differently about our data (Mazzei, 2007). These discursive moves shape the category boundary of the 'normal/abnormal', while at the same time, they are also a product of it. What are the effects of 'silences'? How does 'silence' position subjects? In discourse analysis, the qualitative researcher looks for meaning but meaning can be masked if one only interrogates the spoken in the data. 'Silences' have much to teach the researcher (Mazzei, 2007).

In examining the 'silences', it is crucial not to create a binary between speech and 'silence', that is between what one says and what one does not say, but instead, theorising with Foucault, it seems:

[w] must try to determine the different ways of not saying such things, how those who can and those who cannot 
Silence and its mechanisms as the discursive production...

speak of them are distributed, which type of discourse is authorised, or which form of discretion is required in either case (Foucault, 2008, p.27).

'Silences' pervade discourses and become part of them to exclude those who do not 'speak' from the authorised (normal) discourse and in contrast privilege those who do.

We focus on two every day, and in many ways, 'invisible' or seemingly 'unremarkable' actions that accompany silence: 'moving away' and 'ignoring'. We understand these practices as effects of the constitution of the 'normal/abnormal' (re)produced by the unmarked children. To begin this analysis, we start with an observation where two unmarked children encounter each other in a sandpit and mobilize power to remove a child with a diagnosis who disturbs 'normal play'. In drawing attention to this interaction, we aim to show how it juxtaposes the rest of the data, where the unmarked children's encounters with the marked child, produce a very different effect through 'silence'.

\section{Not Silent}

Elliot (a child without a diagnosis) is in the sandpit digging a deep hole and I am sitting nearby.

Elliot: "Come and see how big my hole is."

Me: “It's huge!"

Kane (a child without a diagnosis) moves closer to take a look and stands in Elliot's freshly dug hole.

Elliot: “Get out of it!” (loud and angry)

Kane: “No, I'm not."

Elliot: (to researcher) "He's in my hole.......he's in my hole."

Karen (researcher) does not respond verbally but gives Elliot a sad look.

Kane: "I'm not getting out.....it's everyone's hole." (Kane is now stomping in the hole making the sides collapse inward, the big hole is getting smaller.)

Elliot: “No, stop doing it.........I'm strong!” (standing his ground and looking into Kane's eyes)

Kane: "I'm strong." (staring straight back at Elliot)

They start to push each other. Kane uses a spade and pushes it into Elliot's chest.

Elliot's twin sister Penny (a child without a diagnosis) moves in on the scene. She gives Kane a big shove in his chest and says: "Don't do that!"

Kane falls backward onto the sand and out of the hole.

Kane: “I'm going to play somewhere else!” (Looking angry and defeated.)

Elliot: “Good!"

Kane runs off and Elliot re-digs his hole.

A teacher who had been sitting at the other end of the sandpit approached me and asked me why I had not intervened. I said that I thought the children could best resolve it themselves. She looked at me with surprise. (Watson, 2017, pp.152-153)

This scene of a child digging a hole in a sandpit would be considered a 'normal' activity in any preschool day. Sandpits adorn most, if not all, preschool playgrounds in Australia. Pedagogical, developmental and historical discourses inform early childhood practitioners of the value of 'sensory experiences' (Winderlich, 2012) and the potential of sensory learning for development made available in sandpit play. In addition, the sandpit provides a place for social interactions and social development as well as a space where fine and gross motor skills can potentially progress (Jarrett, French-Lee, Bulunuz, \& Bulunuz, 2010). Sand pit play also encompasses rules about particular ways of playing and being in the sandpit, which might be problematic for some children. Sandpit play as a discursively constructed activity produces a code of conduct that individuals take up to manage the space and each other.

Elliot draws attention to the hole he has dug and enthusiastically asks the researcher to look at it. He positions himself as playing in the sanctioned way. His hole digging performance demonstrates his category membership with 'the normal' and as he draws adult attention to his achievement he reinforces 
this membership. However, with the arrival of Kane, Elliot now needs to re-position himself to defend his category as 'normal'. Kane disrupts the acceptable way to play by standing in the hole and making movements to cave it in. Elliot responds by asking for my assistance to reconcile the situation.

Elliot uses the strategy of "use your words", an endorsed form of resolving conflict in the classroom, to tell Kane to get out of his hole. "Use your words" is a very familiar phrase encouraged by adults and children in many 'Western' early childhood settings to assist in resolving conflict (Blank \& Schneider, 2011). Kane responds with another acceptable strategy by saying that: "it's everyone's hole". He refers to the norm, that the children are often reminded about: preschool equipment and toys 'belong' to everyone. This pedagogical expectation in the early childhood classroom is thought to inspire children to learn to share. According to some pedagogical frames, 'sharing with others' shows a developing theory of mind and growing moral awareness (Arthur, Powell, \& Lin, 2014). Others argue that 'sharing with others' is an indicator or a milestone in social competency as it encourages young children to develop friendships (McDevitt \& Ormrod, 2007). This pedagogical approach forms a part of the normal way of being in this early childhood classroom, and sets the rule: 'everyone is to share everything at preschool'.

Both children have drawn on these acceptable and sanctioned behavioural and pedagogical discourses in this 'standoff'. Elliot then comments on his physical strength: "No, stop doing it..........I'm strong!" to which Kane replies the same. The children's voices increase in volume and emotion, as they demonstrate power. They now take up masculine discourses (Blaise, 2005; Davies, 1989), arguably also acceptable in this context, and the 'standoff' continues by becoming more physical. Elliot's twin sister Penny moves in to provide a resolution. Penny, perhaps drawing on 'sisterly' protective discourses, is looking out for her brother. She is also conceivably drawing on a discourse that produces a particular code of conduct in the sandpit, where it is not acceptable to jump in to another person's hole or push someone using a spade.

Elliot at first tried to maintain his category membership by using various strategies to remain recognisable as 'normal', but as Kane became more aggressive (drawing on acceptable discourses of masculinity while also taking it to an unacceptable extent), Elliot might have appeared to run out of options, his only choice seem to be to retreat. Penny reclaimed the hole for Elliot by giving Kane a "big shove in his chest" and saying: "Don't do that!" Kane left the sandpit with the comment "I'm going to play somewhere else". His way of engaging in the sand was not tolerated, and Penny and Elliot let him know this. What is interesting here, as it will soon become apparent, was that Kane's behaviour was not ignored; it was confronted, spoken about, and dealt with. He left the sandpit. He had been put back into place to uphold the social order and a distinct code of conduct. Kane challenged the social order, but the children themselves eventually maintained it. Adult intervention was not necessary as the 'normal' with the support of Elliot and Penny did its regulatory work on Kane.

\section{Silence: Moving Away}

On this morning, there is a lot activity in the sandpit. There are about ten children digging and building. As I start to observe, I notice Michael (a child with a diagnosis), on the edge of the sandpit with a teacher nearby. Anna, Michaela and Lucy (children without diagnoses) are sitting in the middle of the sandpit in a circle formation digging a deep hole. Michael, who has been digging on his own about a metre away, stands and moves over towards them and starts to stomp on the hole they have been digging. Nothing is said. The girls observe him while he destroys their hole, with their eyes wide and open mouthed. They wait. After about a minute Anna says: "Hey let's make a castle over here (she stands up and moves) ... over here". Anna beckons the others to follow as Michael has now destroyed the hole they had dug (Watson, 2017, p.155).

In the early childhood classroom authoritative regulatory discourses regarding the 'right way to play' are ubiquitous (Grieshaber \& McArdle, 2010). Often intertwined with these regulations and rules are psychological discourses of social competency and social development, prescribing appropriate ways to play and interact. Anna, Lucy and Michaela seem to understand the sand pit 'etiquette' playing as the 'normal' sandpit player. In performing this position, one must share the space, must not ruin others' work in the sandpit, and generally cooperate with the other children and share. Michael might have a different perspective on sandpit play. Perhaps, he builds so he can destroy, practicing his 'trajectory' and 'vertical 
Silence and its mechanisms as the discursive production...

schema', concepts known from developmental psychology (Atherton \& Nutbrown, 2013). However, in this discursive context, where the imperative is to 'use words' and 'play co-operatively', Michael's way is not an 'acceptable' practice.

When Michael destroys the hole the others have been digging, they do not outwardly protest, they say nothing. It is the unsaid that makes exclusion visible. Their silence 'speaks'. It articulates and makes public their normal position in the discourse and their positioning of Michael as 'not normal', for whom the rules of play in the setting do not always apply, who can be exempted from the rules. Ferfolja (2008) acknowledges that normative discourses on some levels impose 'silences', which consequently marginalise those who are positioned outside the norm. The children, look at Michael silently, eyes wide, mouths open, referring to each other. They wait for a minute and then move away together. They observe him destroying the hole but do not engage with him. By moving away and disassociating themselves from Michael, they maintain their recognisability as 'normal' and their membership in the 'normal' category. At the same time their category boundary work reinforces Michael's positioning as 'not normal'.

The unmarked children here do not say anything to Michael, they silently move on. Foucault argues that "[p]eople know what they do; they frequently know why they do what they do; but what they don't know is what what they do does" (Dreyfus \& Rabinow, 1982, p. 187). The children in their silence and actions 'do' something. Their actions exclude Michael subjecting him as the 'not normal' and not the same as them. They do not acknowledge his way of being, they reject his action as not a part of theirs and do not attempt to explicitly discipline him. They move away, which disassociates them from Michael's 'unruly' action that might also mark them as 'not normal'. This stands in contrast to the many other occasions where thee ethnographer observed children, boys as well as girls, explicitly regulating the other. They would loudly complain and ask for adult help when someone destroyed their sand creations, as Elliot did in the previous scenario. When Michael acted, different discourses are drawn on as the children make sense of his play. Avoiding Michael, leaving him to stomp in their hole without a protest, makes visible how the discourses that produce the marked child shape something that is unspeakable, a silence or a 'taboo' around the discursive subject. The unmarked children's 'silence' also (re)produces the category of the 'normal' for themselves that beckons them to move away. They position themselves by not participating in the situation created by the unruly behaviour of Michael, associated this time with his diagnosis. The unmarked children in their ignorance of the actions of the 'child with the diagnosis' declare their category membership in the 'normal', while at the same time indicating the unacceptability of the disruption to the social order of the sandpit caused by the marked child. In the previous scenario, the unruly behaviour of Kane was understood within the frame of 'normal behaviour' applicable for each child in the early childhood setting. In this scenario, 'acting normal' was a positioning available only for children who form the including group, the 'normal', positioning Michael as the 'not normal' in this setting.

\section{Silence: Ignoring}

In the following scenario, the 'child with the diagnosis' is loud and heard by children.

Teacher Odette has been struggling with Sam (a child with a diagnosis) for about 15 minutes trying to keep him away from the door. She looks to another teacher Anne and says: "Just debating whether I should let him go?" As she speaks, the director Sue arrives on the scene, leaving her office possibly because of the noise Sam is making while crying and banging on the door. Sue picks up Sam off the floor near the door opening to the outside area and takes him back inside the room. Sam kicks and screams even more loudly. A group of children (children without a diagnosis) are sitting on the veranda nearby, eating their morning tea. Only two children of the group turn to look briefly at Sam and the director Sue. The rest of the children just continue not seeming to notice what is going on (Watson, 2017, p. 166).

When observing this scene the ethnographer asked herself: How did the children not respond to this child's crying and screaming? However, in thinking more about it, they did respond. The response was to silently ignore. The early childhood classroom promotes particular disciplinary practices, which work to 'civilise' (Leavitt \& Power, 1997) children by regulating their behaviour and emotions. In particular, sounds and feelings are scrutinised and controlled by educators (Millei, 2005, p. 133). For example, there is 'inside voice' and 'outside voice' and there is 'quiet time'. These regulatory discourses normalise, discipline and 
homogenise actions in the classroom (Davies, 1983). There are certain ways to 'be' and 'act' and being quiet inside is one of those. Sam's loud protest is ignored. The silence of the children suggest that they read Sam's actions as unacceptable for a 'normal' child as it clearly transgressed these civilizing rules and normalizing discourses. In silence, the children (without a diagnosis) distanced themselves from Sam's act and continued eating in a civilized manner their meal. Eating in silence and screaming re/produced the binaries of 'normal' and 'not normal'.

Sam might also be subjected in this context, by particular 'regimes of truth' produced by special education and psychological discourses. His 'characteristics', 'symptoms' and possible actions warranted by his diagnosis, make him who he is. They construct a way of 'knowing' him: 'a child with $x$ diagnosis who is often loud or defies authority'. A diagnosis provides the means to identify and describe his "abnormality and the rationale for intervention when reality and normality fail to coincide" (Rose, 1999, p. 133). The unmarked children know Sam this way. According to Laws and Davies (2000), a person who has a marked difference (in this case a diagnosis) is often the target of pathologizing discourses from an early age. By constituting themselves through the 'othering' of 'the child with the diagnosis' (so to remain not pathological), they reject from themselves those possibilities that do not fit with the way they understand their 'I' to be. Sam's positioning as a child with some pathologies deviate from how they position themselves, as 'without'. As Davies (2006, p. 72) explains, individuals, in our case Sam, "can deviate but their deviation will give rise to category maintenance work". The very act of ignoring through which the unmarked children looked over Sam transgressing the rules, made their maintenance - keeping themselves within the category of 'not pathologized' - work visible. By seemingly not noticing, not talking about and not attending to the transgression, silence was created, which we will return to later.

\title{
Silence: Turning Away
}

\begin{abstract}
Hugo (a child with a diagnosis) approaches the small trestle table to have his fruit break. He sits down with his banana shaped container but as he cannot open it he hands it to the researcher without a word. The researcher opens it for him. As the other children (without a diagnosis) at the table continue to eat, Hugo turns himself around so that his back is now facing the children opposite and he begins to make loud roaring like noises. Sitting at the table with the pre-schoolers is a child (without a diagnosis) who is having an orientation visit with his parent. Hugo stands and walks toward the parent 'roaring' loudly at them with his face very close to their face. The parent, eyes wide and mouth open and then frowning, turns her body away from Hugo and looks around her. She does not respond to Hugo. The other children at the table look at Hugo with wide eyes and open mouths also. They continue to eat their fruit (Watson, 2017, p. 180).
\end{abstract}

At fruit break the children without a diagnosis regulated themselves sitting quietly and eating their fruit. Children in early childhood classrooms become familiar with the rules, routines and restrictions aimed at their bodies, as preschools are one of the first institutions outside the family "where children's bodies are constituted and regulated through institutionalised discourses" (Millei and Cliff, 2014, p. 245). Hugo 'roared'. Hugo's 'roaring' at the visiting parent was met with 'silence' from the parent and the children. The parent turned away her body and looked away possibly indicating her discomfort with the loud roaring and closeness of Hugo. The parent possibly mobilized a discourse around discipline or behaviourism, which suggests one should not reward undesirable behaviour with attention or just simply expressing puzzlement this way. Hugo could have been playing a particular game or creating a character using his imagination. He could have been attempting to invite the others to join his game or he may have been using his 'roar' as a welcome to the parent as if acting a lion or an invitation to play. The parent could have engaged in this game or asked: 'Are you a lion?' The parent could have told Hugo to stop or reminded him of table manners. Instead the parent looked around, perhaps looking for clues to understand what was going on, and in the silence of the table the clue was given. The unmarked children ignored Hugo and remained silent. The parent avoided eye contact with Hugo and ignored him too.

By drawing on Tomkin's definition, Skattebol (2010, p. 78) describes affect as "a tangible, embodied force that operates between people", and that works at a physiological level and "beyond consciousness" to organize intersubjective relations. Skattebol (2010, p. 78) continues by explaining that "[a]ffects are generative and contagious; they are innate activators themselves, for example, shame can produce a blush - the red heat that in turn produces more shame". The discomfort generated by Hugo's 'roar' and the 
Silence and its mechanisms as the discursive production...

closeness of his body might have made the parent feel as if under 'attack'. The parent looked around possibly scanning the table and the playground for some help to make sense of Hugo's action. The children without a diagnosis acted in a required manner, within the rules, and ignored Hugo. Their actions did not only inscribe Hugo as 'unruly' but perhaps also made his unruliness acceptable. Hugo's 'unruliness' was tolerated. At this moment on the borderline of being 'unruly' or something else not yet comprehended or fully expressed, Hugo was constituted on the latter side. The silence and the tolerance positioned him on the "other side of the border" (Davies, 2006, p. 75). Perhaps feeling under attack due to the 'unruly' behaviour and physical proximity that was tolerated despite the discomfort it produced, the parent and unmarked children silently agreed to position Hugo as a potentially 'dangerous' subject - dangerous of invading other's space, potentially contacting others' bodies uninvited or being loud that violates others' peace, thus better 'turned away' from. The generative effect of of discomfort in this situation helped produce Hugo as 'dangerous'. There is 'danger' in his potential to disrupt the social order and there is 'danger' in becoming unrecognisable as the 'normal' if one engages with him.

\section{The Elephant in the Room}

We find the idiom 'the elephant in the room' helpful to discuss how the discourses and their effects produced something that was better ignored, moved or turned away from, or tolerated in silence in these early childhood classrooms. 'The elephant in the room' makes its presence felt by taking up space and being awkward. It is never talked about or addressed directly, but is nevertheless created by the shared obviousness. Acknowledging the marked child's behaviours in these mainstream classrooms became a taboo, which the unmarked children accept and uphold.

Douglas (1966) argues that a taboo is one way of dealing with difference. Avoiding the anomalous, she asserts, "affirms and strengthens the definitions to which they do not conform" (Douglas, 1966, p. 39). If a person has no place in the social system, they become regarded as a marginal being. The marginal being incites fear and precaution against its dangerousness that springs from the 'normal' as the marginal "cannot help his abnormal situation" (Douglas, 1966, p. 97). Silence, in its different forms, was enacted to tolerate the marginal, while at the same time it was performed as a precaution. Perhaps these actions were intended to include, however, the practices of ignoring, moving away and becoming complicit produced forms of exclusion that we have made visible here with our analysis. They created a shared 'taboo': 'the elephant in the room'.

\section{Discussion}

The implications of the perspectives offered here are many. By problematizing everyday practices and understandings, we, like many other Foucauldian researchers, seek to enable a 'practice of freedom', which means opening up possibilities for thinking and acting 'otherwise,' and the potential of pedagogy as discursive practice. The pedagogy of discursive practice draws on "generative philosophies and understandings that make possible ... teachers' pedagogies of social justice [that] lie in their capacity to examine critically the social processes and discourses that shape their ways of teaching and their students' ways of learning" (Nayler, \& Keddie, 2007, p. 212). Part of this pedagogy is giving up all references to things being 'normal' or 'natural' and taking seriously that everything (people, categories, classrooms, diagnoses, etc.) is continuously made and that we are all implicated in making them. As researchers, we are shaped by our own take up of the 'normal' and our own positioning in the re/production of the binaries in the 'inclusive' setting. Thus, we are cognizant about the ways in which our analysis further positions children with a diagnosis, despite our attempts to gaze on the 'normal'. Understanding how these practices are historically and culturally contingent allows researchers and practitioners to examine which practices seem to have taken hold, or seem to dominate in particular places, and what the effects of these are. For this work, we suggest to grapple with the following questions:

- How do the markings (with a diagnosis or without a diagnosis) and discourses I have taken up as my own compel me to think and act? 
- What do these discourses compel me to do and feel and say, or remain silent about or ignore in the everyday flows in the classroom?

- In what way may I be implicated in continuing to categorize and position myself and others that get in the way of a practice that engages with difference differently?

Specifically, in terms of the suggestions around the idiom of 'the elephant' we have offered here, practitioners can ask themselves how they and the other human and non-human actors in their own contexts contribute to or disrupt the marginalization of marked children through the taboo producing practices that we have explored here. What do the active and sustained silences and ignoring around 'uncomfortable difference' achieve? We suggest that they achieve a separation and isolation that remains unaddressed, and therefore produces fear that further separates. Harwood (2010) in a similar way contends that pathologising discourses create isolation. She draws a connection to Foucault's discussions of asylums in Madness and Civilisation: A History of Insanity in the Age of Reason (1967), referring to the discursive power of the diagnosis and how it might move with the pathologised child, containing the child in a 'mobile asylum'. Here, we have offered a few different ways to illustrate how children without a diagnosis ignore and move away from the child with a diagnosis. Maintaining separation, these practices indeed seem to create a 'mobile asylum' in which the child is kept contained within the inclusive setting. Even those actions that might make 'good sense' in the case of another child (without a diagnosis), the actions of the child with a diagnosis are understood in terms of the diagnosis assigned to them by psychological and medical discourses. Children also learn how these children are "best contained". Children come to learn that difference is problematic and un- sanctioned ways of being and acting in early childhood classroom bring about feelings of discomfort. They also learn that one way of acting in the face of difference is to not ask questions or offer alternative positionings. This line of thought provokes us to think about what we could do to disrupt practice-as-usual? Are there ways of talking about, acknowledging and addressing difference in differently productive ways? Perhaps as teachers we could stop creating difference as problematic, and something that needs to be silenced, changed or fixed. We could interrupt our incessant speaking of 'otherness' and instead challenge 'sameness'. We could break the habit of overlooking the unfair encounters we witness between children and between adults and children, where some children are ignored, isolated or separated. We could learn to address the silences and 'the elephant in the room' and start discussing difference, and with that become curious and open to the uncertainty.

We realise that in this paper we offer many questions to explore in one's own practice. We believe in the power of new thought and in the possibilities that thinking anew, or thinking again, affords. Of course, collegial discussions around this, policy advocacy and so on are central to making change happen, yet these efforts are in vain if they are not infused with new insights on old practices.

\section{Declarations}

Funding: This work was not supported by any funding.

\section{References}

Alderson, P. (2008). Children as Researchers: Participation Rights and Research Methods. In P. Christensen \& A. James (Eds.), Research with Children: Perspectives and Practices (2nd ed., pp. 276-290). New York: Routledge.

Allan, J. (2010). The sociology of disability and the struggle for inclusive education. British Journal of Sociology of Education, 31(5), 603619. https://doi.org/10.1080/01425692.2010.500093

Arthur, J., Powell, S., \& Lin, H-C. (2014). Foundations of character: methodological aspects of a study of character development in three- to six-year-old children with a focus on sharing behaviours. European Early Childhood Education Research Journal, 22(1), 105-122. https://doi.org/10.1080/1350293X.2012.707413

Atherton, F. \& Nutbrown, C. (2013) Understanding Schemas and Young Children: From Birth to Three. SAGE Publishing. https://doi.org/10.4135/9781526435866

Beazley, S. \& Williams, V. (Eds.) (2014). Childhood and disability: Key papers from disability and society. United Kingdom: Routledge.

Blaise, M. (2005). Playing it straight; uncovering gender discourses in the early childhood classroom. New York: Routledge. 
Silence and its mechanisms as the discursive production...

Blank, J., \& Schneider, J.J. (2011). "Use Your Words": reconsidering the language of conflict in the early years. Contemporary Issues in Early Childhood, 12(3), 198-211. https://doi.org/10.2304/ciec.2011.12.3.198

Burman, E. (2008). Deconstructing developmental psychology. East Sussex, U.K: Routledge. https://doi.org/10.1017/S0954579408000394

Butler, J. (2004). Undoing Gender. Hoboken: Taylor and Francis. https://doi.org/10.4324/9780203499627

Cannella, G. S. (1997). Deconstructing early childhood education: Social justice \& revolution. New York: Peter Lang.

Christensen, P. (2004). Children's participation in ethnographic research: Issues of power and representation. Children and Society, 18(2), 165-176. https://doi.org/10.1002/chi.823

Cologon, K. (2014). Preventing inclusion? Inclusive early childhood education and the option to exclude. Contemporary Issues in Early Childhood, 15(4), 378-381. https://doi.org/10.2304/ciec.2014.15.4.378

Connolly, P., Smith, A., \& Kelly, B. (2002). Too young to notice? The cultural and political awareness of 3-6 year olds in Northern Ireland. Belfast: Community Relations Council.

Dalkilic, M., \& Vadeboncoeur, J. A. (2016). Regulating the child in early childhood education: The paradox of inclusion. Global Studies of Childhood, 6(1), 17-30. https://doi.org/10.1177/2043610615619982

Davies, B. (1983). The role pupils play in the social construction of classroom order. British Journal of Sociology of Education, 4(1), 55-69. https://doi.org/10.1080/0142569830040104

Davies, B. (1989). Frogs and snails and feminist tales: Preschool children and gender. Sydney: Allen \& Unwin.

Davies, B. (1993). Shards of glass: Children reading and writing beyond gendered identities. Sydney: Allen \& Unwin.

Davies, B. (1998). The politics of category membership in early childhood settings. In N. Yelland (Ed.), Gender in Early Childhood. (pp. 131-148. London: Routledge.

Davies, B. (2006). Identity, abjection and otherness: Creating the self, creating difference. In M. Arnot \& M. Mac an Ghaill (Eds.), The Routledge Falmer Reader in Gender and Education (pp. 72-90). London: Routledge.

Davies, B., \& Harré, R. (1999). Positioning and Personhood. In R. Harré \& L. van Langenhove (Eds.), Positioning Theory: Moral contexts of intentional action (pp. 32-52). Oxford: Blackwell Publishers.

Davis, J. M. \& Watson, N. (2001). Where are the children's experiences? Analysing social and cultural exclusion in 'special' and 'mainstream' schools. Disability and Society, 16(5), 671-687. https://doi.org/10.1080/09687590120070060

Douglas, M. (1966). Purity and danger: An analysis of concepts of pollution and taboo. London: Routledge.

Dreyfus, H. L., \& Rabinow, P. (1982). Michel Foucault: Beyond structuralism and hermeneutics. Brighton, Sussex: The Harvester Press Limited. https://doi.org/10.7208/chicago/9780226154534.001.0001

Ferfolja, T. (2008). Discourses that silence: teachers and anti-lesbian harassment. Discourse: studies in the cultural politics of education, 29(1), 107-119. https://doi.org/10.1080/01596300701802805

Ferreira, J M. (2018). Inclusive early childhood education and the role of peer interaction: Brazil and Finland in dialogue (Unpublished PhD thesis). Tampere University Press, Tampere, Finland.

Foucault, M. (1967). Madness and civilisation: A history of insanity in the age of reason. London: Routledge.

Foucault, M. (1972). The archaeology of knowledge and the discourse on language. New York: Pantheon.

Foucault, M. (1977). Discipline and punish: The birth of the prison. London: Penguin.

Foucault, M. (2008). The history of sexuality: The will to knowledge volume 1. U.S.A.: Penguin Group.

Graham, L. (2006). Caught in the Net: A Foucaultian interrogation of the incidental effects of limited notions of "inclusion". International Journal of Inclusive Education, 10(1), 3-24. https://doi.org/10.1080/13603110500173217

Graham, L. J., \& Slee, R. (2008). An Illusory Interiority: Interrogating the discourse/s of inclusion. Educational Philosophy and Theory, 40(2), 277-293. https://doi.org/10.1111/j.1469-5812.2007.00331.x

Grieshaber, S., \& McArdle, F. (2010). The trouble with play. New York: Open University Press.

Harré, R., \& van Langenhove, L. (Eds.). (1999). Positioning Theory: Moral contexts of intentional action. Oxford: Blackwell Publishers.

Harwood, V. (2006). Diagnosing 'disorderly' children; A critique of behaviour disorder discourse. London: Routledge. https://doi.org/10.4324/9780203481936

Harwood, V. (2010). Mobile asylums: Psychopathologisation as a personal, portable psychiatric prison. Discourse: studies in the cultural politics of education, 31(4), 437-451. https://doi.org/10.1080/01596306.2010.504361

Hedegaard Hansen, J. (2012). Limits to inclusion. International Journal of Inclusive Education, 16(1), 1-10. https://doi.org/10.1080/13603111003671632 
James, A., Jenks, C., \& Prout, A. (1998). Theorizing childhood. Cambridge, U.K.: Polity Press.

Jarrett, O., French-Lee, S., Bulunuz, N., \& Bulunuz, M. (2010). Play in the Sandpit: A University and a Child-Care Center Collaborate in Facilitated-Action Research. American Journal of Play, 3(2), 221-237.

Koster, M., Nakken, H., Pijl, S.J., \& van Houten, E. (2009). Being part of the peer group: A literature study focusing on the social dimension of inclusion in education, International Journal of Inclusive Education, 13(2), 117-140. https://doi.org/10.1080/13603110701284680

Laws, C., \& Davies, B. (2000). Poststructuralist theory in practice: Working with "behaviourally disturbed" children. International Journal of Qualitative Studies in Education, 13(3), 205-221. https://doi.org/10.1080/09518390050019631

Leavitt, R. L., \& Power, M.B. (1997). Civilising bodies: Children in day care. In J. Tobin (Ed.), Making a place for pleasure in early childhood education (pp. 39-75). Michigan: Edward Brothers.

MacArthur, J. (2013) Sustaining friendships, relationships, and rights at school. International Journal of Inclusive Education, 17(8), 793811. https://doi.org/10.1080/13603116.2011.602526

MacLure, M., Jones, L., Holmes, R., \& MacRae, C. (2012). Becoming a problem: Behaviour and reputation in the early years classroom. British Education Research Journal, 38(3), 447-471. https://doi.org/10.1080/01411926.2011.552709

Mazzei, L. A. (2007). Toward a problematic of silence in action research. Educational Action Research, 15(4), 631-642. https://doi.org/10.1080/09650790701664054

McDevitt, T. M., \& Ormrod, J.E. (2007). Child development and education (3rd ed.). New Jersey: Pearson.

Millei, Z. (2005). The Discourse of control: Disruption and Foucault in the early childhood classroom. Contemporary Issues in Early Childhood 6(1), 128-139. https://doi.org/10.2304/ciec.2005.6.2.3

Millei, Z. \& Cliff, K. (2014) The preschool bathroom: Making 'problem bodies' and the limit of the disciplinary regime over children. British Journal of Sociology of Education, 35(2) 244-262. https://doi.org/10.1080/01425692.2012.761394

Nayler, J.M., \& Keddie, A. (2007). Focusing the gaze: Teacher interrogation of practice. International Journal of Inclusive Education, 11(2), 199-214. https://doi.org/10.1080/13603110600586268

Nutbrown, C., \& Clough, P. (2009). Citizenship and inclusion in the early years: Understanding and repsonding to children's perspectives on 'belonging'. International Journal of Early Years Education, 17(3), 191-206. https://doi.org/10.1080/09669760903424523

Petersen, E. B. (2004). Academic boundary work: The discursive constitution of scientificity amongst researchers within the social sciences and humanities (Unpublished doctorate thesis). University of Copenhagen, Copenhagen.

Petersen, E. B. (2007). Negotiating academicity: Postgraduate research supervision as category boundary work. Studies in Higher Education, 32(4), 475-487. https://doi.org/10.1080/03075070701476167

Petersen, E.B., \& Millei, Z. (Eds.) (2016). Interrupting the psy- disciplines in education. London: Palgrave/Macmillan

Purdue, K. (2009). Barriers to and facilitators of inclusion for children with disabilities in early childhood education. Contemporary Issues in Early Childhood, 10(2), 133-143. https://doi.org/10.2304/ciec.2009.10.2.133

Robinson, K. H., \& Jones-Diaz, C. (2006). Diversity and Difference in Early Childhood Education: Issues for theory and practice. New York: Open University Press.

Rose, N. (1999). Governing the Soul: The Shaping of the Private Self (2nd ed.). London: Free Association Books.

Skattebol, J. (2010). Affect: A tool to support pedagogical change. Discourse: Studies in the Cultural Politics of Education, 31(1), 75-91. https://doi.org/10.1080/01596300903465435

Slee, R. (2010). Revisiting the politics of special educational needs and disability studies in education with Len Barton. British Journal of Sociology of Education, 31(5), 561-573. https://doi.org/10.1080/01425692.2010.500089

Slee, R., (2013). How do we make inclusive education happen when exclusion is a political predisposition? International Journal of Inclusive Education, 17(8), 895-907. https://doi.org/10.1080/13603116.2011.602534

Slee, R., \& Allan, J. (2001). Excluding the Included: A reconsideration of inclusive education. International Studies in Sociology of Education, 11(2), 173-191. https://doi.org/10.1080/09620210100200073

Stronach, I., \& MacLure, M. (1997). Educational Research Undone: the postmodern embrace. Buckingham: Open University Press.

Traweek, S. (1988). Beamtimes and lifetimes - The world of high energy physicists. London: Harvard University Press.

United Nations Educational, Scientific and Cultural Organization. (1994). The UNESCO Salamanca Statement and framework for action on special educational needs. Paris: UNESCO.

Walkerdine, V. (1988). The mastery of reason: Cognitive development and the production of rationality. London: Routledge. 
Silence and its mechanisms as the discursive production...

Watson, K. (2015). Interrogating the discursive constitution of the 'normal' in 'inclusive' early childhood education. (Unpublished doctoral dissertation). University Of Newcastle, Australia.

Watson K. (2017) Inside the 'inclusive' early childhood classroom: The power of the 'normal'. New York: Peter Lang. https://doi.org/10.3726/b10726

Winderlich, K. (2012). Sensory play and learning (Vol. 10). Deakin West, A.C.T.: Early Childhood Australia. 